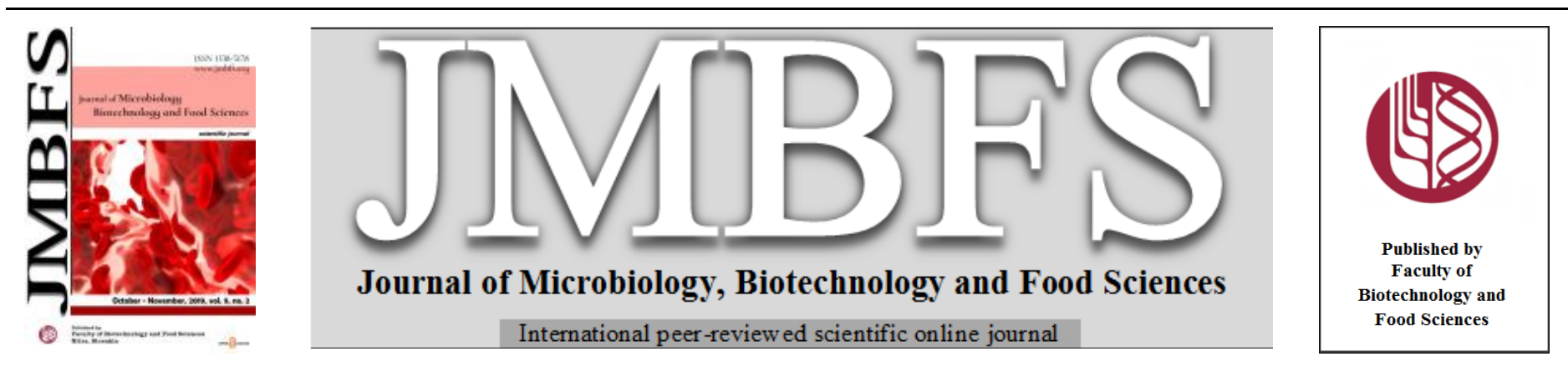

\title{
ASSESSMENT OF GLUTEN-FREE COOKIES MADE FROM RICE AND SOY PROTEIN ISOLATE BLENDS \\ Eunice Moriyike Ogunbusola ${ }^{1 *}$, Opeyemi Olaitan Alabi ${ }^{1}$, Toibudeen Adesegun Sanni ${ }^{1}$, Kudirat Titilope Seidu ${ }^{2}$, Hammed Oluwatobi Oke ${ }^{1}$, Olamide Rebecca Akinwale ${ }^{I}$
}

Address(es): Dr Eunice Moriyike Ogunbusola,

1 Federal University Oye, Faculty of Agriculture, Department of Food Science and Technology, P.M.B 573, Oye, Ekiti Stete, Nigeria

2 Federal University Oye, Faculty of Agriculture, Department of Hospitality and Tourism Management, P.M.B 573, Oye, Ekiti Stete, Nigeria

*Corresponding author: eunice.ogunbusola@fuoye.edu.ng

doi: 10.15414/jmbfs.2020.9.5.907-912

\section{ARTICLE INFO}

Received 30. 10. 2018

Revised 16. 9. 2019

Accepted 22. 10. 2019

Published 1. 4. 2020

Regular article

OPEN $\partial_{\text {ACCESS }}$

\begin{abstract}
The chemical composition, physical characteristics, and sensory attributes of gluten-free cookies made from blends of rice and soy protein flour were evaluated. Nerica 7 and Faro 44 rice were separately blended with soy protein isolate, to produce five formulations with ratio $(100: 0,95: 5,90: 10,85: 15$ and 80:20) of rice to soy protein isolate flour respectively for cookies production. The functional and pasting properties of the composite flour formulations were analysed. The bulk density and the least gelation concentration of the flour blends decreased with increasing percentage of soy protein isolate, while other functional attributes increased. Pasting properties varied significantly $(\mathrm{p} \leq 0.05)$, with whole rice flours having the highest pasting characteristics. Nerica 7 flour blend and its composite blends exhibited better pasting properties than their Faro 44 rice counterpart. Cookies made from Nerica 7 rice flour supplemented with $10 \%$ soy protein isolates had the highest spread ratio. The moisture content, protein and crude fibre content of the cookies ranged from 3.28-5.33 g/100g, 3.96-17.76 g/100g, and 3.09-4.22 g/100g respectively. The results of sensory evaluation showed that the cookies produced from flour blends were scored significantly higher in all the quality attributes compared to whole rice flours (control). Nerica 7 and Faro 44 rice flour composited with soy protein isolate could serve as functional ingredients in food formulation, especially in the production of gluten-free cookies.
\end{abstract}

Keywords: Nerica 7 rice, Faro 44 rice, soy protein isolate, gluten free cookies, functional properties, pasting properties, sensory attributes

\section{INTRODUCTION}

Consumption of cereal snack foods such as biscuits, short bread, wafers and cookies is gaining more popularity in Africa, especially in Nigeria. Most cereal snacks are traditionally produced from wheat flour. The climatic condition in Nigeria does not support the growth of wheat seed (Adeyeye and Akingbala, 2015). Therefore, there is huge reliance on importation of wheat in order to meet up with the increased growing demand for wheat based snacks. The replacement of wheat flour with indigenous cereal such as locally grown rice flour in industrial food applications will reduce economic losses incurred from huge foreign exchange, thereby increasing economic growth.

Furthermore, health-conscious consumers are no longer snacking for enjoyment alone. Hence, they demand snacks suitable for specific health purpose, such as supplying essential nutrients and/or prevention of nutrition-related diseases (Beswa et al., 2016; Norazmir et al., 2014). Therefore, there is need for the production of gluten-free snacks from non-wheat flour. The consumption of gluten-free (GF) cereal-based snacks cater for clinically diagnosed celiac patients, and those seeking to exclude gluten-containing proteins from their diet (Pellegrini and Agostoni, 2015). Therefore, there is need for the production of gluten-free snacks from non-wheat flour.

However, gluten-free snacks have been reported to contain lower resistant starch (RS) and dietary fibre, with higher glycemic index (GI) than its gluten-containing counterparts (Foschia et al., 2017; Giuberti et al., 2018; Pellegrini and Agostoni, 2015). In addition, gluten-free foods have also been reported to contain lower protein content than gluten-containing foods (Wu et al., 2015). Thus, threatening the production of nutritious gluten-free foods (Pestoric $\boldsymbol{e t}$ al., 2017; da Silva and Conti-Silva, 2016). Enrichment of gluten-free confectioneries with legumes such as soy protein; a rich source of lysine, an essential amino acid limiting in most cereals will improve the nutritional composition of the snacks. Nutritious snacks have been produced from various blends from wheat, rice, green gram and potato flours (Chandra et al., 2015), germinated pigeon pea, fermented sorghum and cocoyam flours (Okpala $\boldsymbol{e t}$ al., 2013). There is limited information on the utilisation of locally grown rice
(Nerica 7 and Faro 44) as food ingredients in food system. This study evaluated the chemical composition, physical characteristics, and the sensory attributes of gluten-free cookies produced from blends of rice and soy protein isolate.

\section{MATERIALS AND METHODS}

\section{Procurement of raw materials}

The rice samples (Nerica 7 and Faro 44) were obtained from Agricultural Development Programme (ADP) office at Ikole-Ekiti, Ekiti State, Nigeria Soybean seed and baking ingredients were purchased from the central market in Ado-Ekiti, South western Nigeria.

\section{Preparation of raw materials}

The rice samples were separately ground into flour with the use of well cleaned Hammer mill (Trojan TGS 228 E). The rice flour was sieved through a $500 \mu \mathrm{m}$ screen mesh and packed in an air-tight container prior to use. Soybean grains were sorted and dehulled manually, then ground in a Warring laboratory blender (HGBTWTS3, Torrington, CT, USA) and sieved through a screen mesh of 355 $\mu \mathrm{m}$.

\section{Production of soybean protein isolate}

Soybean flour was defatted overnight using $\mathrm{n}$-hexane solvent in the ratio 1:7 (flour: solvent) on a magnetic stirrer at speed of $198 \mathrm{~g}$. Protein isolate was prepared from defatted soybean meal following the method described by Ogunbusola et al. (2012) with slight modification. Soy protein was extracted with water by adding $20 \mathrm{ml}$ of water to $1 \mathrm{~g}$ flour sample. The mixture was stirred with a magnetic stirrer at speed of $175 \mathrm{~g}$ for $10 \mathrm{~min}$, and the $\mathrm{pH}$ of the slurry was adjusted to 8.0 using $0.1 \mathrm{M} \mathrm{HCl}$ or $0.1 \mathrm{M} \mathrm{NaOH}$ drop wise. The extraction was allowed to continue for $2 \mathrm{~h}$ with constant stirring on a constant temperature magnetic stirrer $(78 \mathrm{HW}-1)$, while the $\mathrm{pH}$ was kept constant. The slurry was 
centrifuged at $8000 \mathrm{rpm}$ for $25 \mathrm{~min}$. The residue was re-extracted with the same solvent under similar conditions. The supernatant was combined and proteins precipitated by adjusting the $\mathrm{pH}$ to 4.5 with $0.1 \mathrm{M} \mathrm{HCl}$, followed by separation by centrifugation (GL16C BBPAN Scientific and Instrument Co Ltd) at 8000 $\mathrm{rpm}$ for $20 \mathrm{~min}$. The insoluble material was dispersed in distilled water transferred into the dialysis tube (Brooklyn, N.Y.11311, USA), and then dialysed against distilled water for $18 \mathrm{~h}$ at room temperature. The dialysing water was replaced at intervals of 3 hours. The dialysate was lyophilised using freeze dryer (Armfield, Model 1793/CPS6352/1) and later stored in an air-tight container for future use.

\section{Preparation of composite flour}

Blends of rice-soy protein isolates were prepared by mixing rice flour and soybean protein isolates according to the formulation depicted in Table 1 .

Table 1 Formulation of rice-soy protein isolate flour blends

\begin{tabular}{lccc}
\hline Sample Code & $\begin{array}{c}\text { Nerica 7 Rice } \\
\text { flour }(\mathbf{g})\end{array}$ & $\begin{array}{c}\text { Faro 44 Rice } \\
\text { flour }(\mathbf{g})\end{array}$ & $\begin{array}{c}\text { Soy Protein } \\
\text { Isolate flour }(\mathbf{g})\end{array}$ \\
\hline NRW & 100 & 0 & 0 \\
FRW & 0 & 100 & 0 \\
NRFvPI & 95 & 0 & 5 \\
FRFvPI & 0 & 95 & 5 \\
NRTnPI & 90 & 0 & 10 \\
FRTnPI & 0 & 90 & 10 \\
NRFtPI & 85 & 0 & 15 \\
FRFtPI & 0 & 85 & 15 \\
NRTwPI & 80 & 0 & 20 \\
FRTwPI & 0 & 80 & 20 \\
\hline
\end{tabular}

Functional properties of composite flours

\section{Determination of bulk density}

The bulk density (BD) of flour blends was determined using the method described by Ige et al. (1984). Some quantity of flour sample was transferred into a pre-weighed empty measuring cylinder $\left(\mathrm{W}_{1}\right)$. The measuring cylinder was tapped for about gently, and its new weight was recorded $\left(\mathrm{W}_{2}\right)$. The volume of flour in the measuring cylinder was recorded as V. The bulk density was calculated using the formula below:

$$
B D\left(\mathrm{~g} / \mathrm{cm}^{3}\right)=\frac{W 2-W I}{V}
$$

\section{Determination of water and oil absorption capacity}

Water and oil absorption capacity (WAC and OAC) were determined using the method of Sathe et al. (1982) described by Omowaiye-Taiwo et al. (2014). Exactly $1.0 \mathrm{~g}$ of the flour sample was measured, and $10 \mathrm{ml}$ of distilled water $(\rho$ $=1.0 \mathrm{~g} / \mathrm{cm}^{3}$ ) was added in a beaker and then stirred using magnetic stirrer for 5 min. The suspension was later centrifuged for $30 \mathrm{~min}$ at $2500 \mathrm{rpm}$. The supernatant was decanted and the volume was recorded. Water absorbed by the flour was calculated as the different between the initial volume of water added and the final volume of supernatant decanted. OAC was determined by replacing water with vegetable oil with density of $0.92 \mathrm{~g} / \mathrm{cm}^{3}$.

\section{Determination of foaming capacity and foaming stability}

Foaming capacity and foaming stability (FC and FS) were determined using the method described by Omowaiye-Taiwo et al. (2014). A known quantity of flour sample was weighed, $100 \mathrm{ml}$ distilled water was added and stirred using magnetic stirrer at $1500 \mathrm{rpm}$ for $5 \mathrm{~min}$. The foaming mixture was immediately dispensed into $250 \mathrm{ml}$ measuring cylinder and the foam volume was measured FC was expressed as percentage volume increase $(\%, v / v)$. FS was expressed as foam volume remaining after $1 \mathrm{~h}$.

Determination of Least gelation concentration and Solubility Index (LGC and SI)

The solubility index was determined using the method of Leach et al. (1959) LGC was determined using the procedure of Coffman and Garcia (1977). Flour suspensions of $2-20 \%(\mathrm{~m} / \mathrm{v})$ were prepared with distilled water. Aliquot of $10 \mathrm{ml}$ from each suspension was put into test tubes and heated in a boiling water bath for $60 \mathrm{~min}$. The tubes were cooled rapidly under running water and then further cooled in a water bath at $4{ }^{\circ} \mathrm{C}$. The LGC was taken as concentration when the gel did not fall or slip when tubes were inverted.

\section{Determination of Pasting Properties of Composite Flours}

The pasting characteristics of whole and composite flour blends were determined using a Rapid Visco Analyser (Newport Scientific Pty Ltd. Warriewood NSW
2102, Australia) hooked on to a workstation. The moisture content of the sample was first determined to obtain the correct sample weight and amount of wate required for the test. An aqueous suspension of the sample $(6 \%$ w/w; $28 \mathrm{~g}$ tota weight) was prepared and spun at $75 \mathrm{rpm}$. The temperature-time conditions included a heating step from 50 to $100{ }^{\circ} \mathrm{C}$ at $6{ }^{\circ} \mathrm{C} / \mathrm{min}$ (after an equilibration time of $1 \mathrm{~min}$ at $50{ }^{\circ} \mathrm{C}$ ), a holding phase at $100{ }^{\circ} \mathrm{C}$ for $5 \mathrm{~min}$, and a cooling step from 100 to $50{ }^{\circ} \mathrm{C}$ for $2 \mathrm{~min}$. Viscosity was expressed in centipoises (cP) (IITA, 2001).

\section{Production of cookies}

About $100 \mathrm{~g}$ of hydrogenated fat, leavening agents and granulated sugar were creamed to a smooth uniform consistency. Required amount of the flour, wate and sodium bicarbonate were added to the creamed mixture, then mixed using a dough mixer to obtain a homogeneous mixture. The resulting dough was rolled out into a thin sheet of uniform thickness and cut into the desired shape using a Cookies-cutter. The cut pieces were placed on a lightly greased perforated pan and baked at $180{ }^{\circ} \mathrm{C}$ for $15-20 \mathrm{~min}$ in an Oven (PBs 118SF Genlab Widnes, England). The cookies were later cooled to room temperature, packed in polyethylene bags and stored for further analysis.

\section{Determination of physical characteristics of cookies}

Width of six cookies placed edge to edge was measured with a Vernier caliper ( $0.01 \mathrm{~mm}$ accuracy) and the average width was calculated (Siddiqui et al., 2003) Similarly, the length of the cookies was determined by placing the butt of six cookies and taking the mean value. The thickness was measured by stacking six cookies on top of each other and taking the average thickness. Weight of cookies was determined as average weight of six cookies measured using a digita weighing balance (CP 413, OHAUS China). Spread ratio was calculated by dividing the average value of width by average value of thickness of cookies.

\section{Determination of proximate composition of cookies}

The cookies were analysed for proximate composition using the method of AOAC (2010). The carbohydrate was calculated by difference.

\section{Sensory evaluation of cookies}

Sensory evaluation of the cookies was carried out by ten semi-trained panelists selected based on familiarity with cookies and their consistency in scoring, using a 9-point Hedonic scale from like extremely to dislike extremely. The samples were evaluated for colour, taste, texture, crispiness and overall acceptability.

\section{Statistical analysis}

Data were analysed using Analysis of Variance ANOVA and mean separated by New Duncan Multiple range test using. Significance was accepted at $5 \%$ level of probability.

\section{RESULTS AND DISCUSSION}

\section{Functional properties of flour blends}

The results of functional properties of flour blends made from rice (Nerica 7 or Faro 44) and varying proportions of soybean protein isolates is shown in Table 2. Bulk density varied significantly $\left(\mathrm{p} \leq 0.05\right.$ ); ranged from 0.62 to $0.85 \mathrm{~g} / \mathrm{cm}^{3}$, with whole Nerica 7 rice flour (NRW) having the highest value, while Nerica 7 rice blended with $20 \%$ soy protein isolate (NRTwPI) had the least value. The range of bulk density compared favourably with the range of $0.762-0.820 \mathrm{~g} / \mathrm{cm}^{3}$ reported for composite flour of wheat, rice, green gram and potato flours (Chandra et al., 2015). The data obtained in this study is however lower than $1.08-1.24 \mathrm{~g} / \mathrm{cm}^{3}$ reported for sweet potato and wheat flour blend fortified with brewer's spent grain flour (Okpala and Ofoedu, 2018). The bulk density of ricesoy protein isolate flours significantly decreased with increased level of protein isolate added. Bulk density is an important parameter required for packing design, and it correlates with relative volume (Udensi and Okoronkwo, 2006). Greater quantity of the flour blends could be packaged within constant volume, which would offer greater packaging advantage. The low values obtained for rice-soy protein flour blend would make it suitable for infant feed formulation where less bulk is desired (Iwe and Egwueke, 2010). The bulk density ( 0.84 $\mathrm{g} / \mathrm{cm}^{3}$ ) reported for whole Faro 44 rice flour in this study compared favourably with the range of $0.87-0.89 \mathrm{~g} / \mathrm{cm}^{3}$ reported for some varieties of Faro rice flours (Sanusi et al., 2017). The high bulk densities of whole Nerica 7 and Faro 44 rice flours suggest their suitability in food preparations. The rice flours and their composite blends may find use in food products as thickeners and in food formulations, especially in children. 
Table 2 Functional properties of rice-soy protein isolate flour blends

\begin{tabular}{llllllll}
\hline Sample & BD $\left(\mathbf{g} / \mathbf{c m}^{3}\right)$ & WAC $(\%)$ & OAC $(\%)$ & FC $(\%)$ & FS $(\%)$ & SI & LGC $(\%)$ \\
\hline NRW & $0.85 \pm 0.01^{\mathrm{a}}$ & $95.35 \pm 0.75^{\mathrm{h}}$ & $58.05 \pm 0.98^{\mathrm{j}}$ & $56.85 \pm 0.94^{\mathrm{f}}$ & $14.42 \pm 0.42^{\mathrm{j}}$ & $20.97 \pm 0.09^{\mathrm{h}}$ & $18.00 \pm 1.00^{\mathrm{a}}$ \\
FRW & $0.84 \pm 0.01^{\mathrm{a}}$ & $72.55 \pm 0.52^{\mathrm{i}}$ & $60.47 \pm 0.28^{\mathrm{i}}$ & $21.49 \pm 0.54^{\mathrm{i}}$ & $16.11 \pm 0.84^{\mathrm{i}}$ & $21.25 \pm 0.22^{\mathrm{h}}$ & $19.00 \pm 0.58^{\mathrm{a}}$ \\
NRFvPI & $0.74 \pm 0.01^{\mathrm{d}}$ & $102.89 \pm 0.38^{\mathrm{g}}$ & $101.56 \pm 0.47^{\mathrm{g}}$ & $59.99 \pm 1.11^{\mathrm{e}}$ & $34.23 \pm 0.58^{\mathrm{f}}$ & $36.25 \pm 0.21^{\mathrm{d}}$ & $17.00 \pm 0.58^{\mathrm{b}}$ \\
FRFvPI & $0.81 \pm 0.005^{\mathrm{b}}$ & $94.65 \pm 0.36^{\mathrm{h}}$ & $75.77 \pm 0.30^{\mathrm{h}}$ & $27.68 \pm 0.26^{\mathrm{h}}$ & $21.39 \pm 0.45^{\mathrm{h}}$ & $31.13 \pm 0.17^{\mathrm{g}}$ & $17.00 \pm 0.58^{\mathrm{b}}$ \\
NRTnPI & $0.72 \pm 0.01^{\mathrm{e}}$ & $103.49 \pm 0.53^{\mathrm{e}}$ & $123.85 \pm 0.68^{\mathrm{e}}$ & $73.82 \pm 0.33^{\mathrm{d}}$ & $42.30 \pm 0.61^{\mathrm{e}}$ & $35.32 \pm 0.99^{\mathrm{e}}$ & $15.00 \pm 0.58^{\mathrm{c}}$ \\
FRTnPI & $0.78 \pm 0.005^{\mathrm{c}}$ & $111.68 \pm 0.71^{\mathrm{f}}$ & $103.17 \pm 0.91^{\mathrm{f}}$ & $33.71 \pm 1.25^{\mathrm{g}}$ & $30.66 \pm 0.55^{\mathrm{g}}$ & $32.73 \pm 0.35^{\mathrm{f}}$ & $13.00 \pm 0.58^{\mathrm{d}}$ \\
NRFtPI & $0.68 \pm 0.01^{\mathrm{f}}$ & $167.96 \pm 0.51^{\mathrm{c}}$ & $155.98 \pm 1.01^{\mathrm{c}}$ & $88.89 \pm 0.21^{\mathrm{c}}$ & $57.08 \pm 0.23^{\mathrm{c}}$ & $40.25 \pm 0.12^{\mathrm{c}}$ & $11.00 \pm 0.58^{\mathrm{e}}$ \\
FRFtPI & $0.74 \pm 0.005^{\mathrm{d}}$ & $153.52 \pm 0.30^{\mathrm{d}}$ & $143.42 \pm 0.58^{\mathrm{d}}$ & $61.16 \pm 1.04^{\mathrm{e}}$ & $54.47 \pm 1.26^{\mathrm{d}}$ & $42.92 \pm 0.22^{\mathrm{b}}$ & $8.00 \pm 0.58^{\mathrm{e}}$ \\
NRTwPI & $0.62 \pm 0.01^{\mathrm{g}}$ & $205.49 \pm 0.33^{\mathrm{b}}$ & $202.66 \pm 1.33^{\mathrm{a}}$ & $107.16 \pm 0.82^{\mathrm{a}}$ & $87.29 \pm 0.40^{\mathrm{a}}$ & $40.88 \pm 0.51^{\mathrm{c}}$ & $5.00 \pm 1.00^{\mathrm{h}}$ \\
FRTwPI & $0.68 \pm 0.01^{\mathrm{f}}$ & $233.38 \pm 0.59^{\mathrm{a}}$ & $195.35 \pm 0.91^{\mathrm{b}}$ & $94.69 \pm 0.58^{\mathrm{b}}$ & $80.33 \pm 0.34^{\mathrm{b}}$ & $52.97 \pm 0.07^{\mathrm{a}}$ & $7.00 \pm 1.00^{\mathrm{g}}$ \\
\hline
\end{tabular}

Legend: Values are means of triplicates \pm Standard deviation. Values on the same column with different superscripts are significant $(\mathrm{P} \leq 0.05)$. NRW - Whole Nerica 7 rice flour, FRW Whole Faro 44 rice flour, NRFvPI Nerica 7 rice $+5 \%$ soy protein isolate, FRFvPI Faro 44 rice $+5 \%$ soy protein isolate, NRTnPI - Nerica 7 rice $+10 \%$ soy protein isolate, FRTnPI - Faro 44 rice $+10 \%$ soy protein isolate, NRFtPI - Nerica 7 rice $+15 \%$ soy protein isolate, FRFtPI - Faro 44 rice $+15 \%$ soy protein isolate, NRTwPI - Nerica 7 rice $+20 \%$ soy protein isolate, FRTwPI - Faro 44 rice $+20 \%$ soy protein isolate.

The water and oil absorption capacities (WAC and OAC) varied significantly in the flour samples. WAC and OAC ranged between $72.55-233.38 \%$ and $58.05-$ $202.60 \%$ respectively. Highest WAC was recorded in FRTwPI and lowest in FRW, while the highest OAC was recorded in NRTwPI and least in NRW. As the soy protein isolate inclusion increases, the WAC and OAC of the flour blends significantly increases. This could be attributed to the increased protein content of flour blends thus enhancing better interactions between the protein and solvent. In addition, proteins have both hydrophilic and hydrophobic amino acids which further encouraged more interaction with water and oil. The non-polar amino acid side chains can form hydrophobic interaction with the hydrocarbon chains of lipids, thus high OAC recorded in protein isolate substituted flour blends compared to whole rice flours (Jitngarmkusol $\boldsymbol{e t}$ al., 2008). The high WAC and OAC of the composite flour blends especially NRTwPI and FRTwPI may be an indication of their potential usage in food products where good viscosity and thickening are required such as gravies and soups. The WAC and OAC of the composite flours obtained for this study is in similar trend with that of $2.12-2.63 \mathrm{~g} / \mathrm{g}$ for composite flours from potato, cassava, rice, soyabean and xanthan gum (Tharise et al., 2014) and the range of $1.87-2.08 \mathrm{~g} / \mathrm{g}$ for pigeon pea, sorghum and cocoyam flours (Okpala et al., 2013). Oil absorption capacity is important because of the flavour retention function of oil and its enhancement of palatability, particularly in bakery and meat products (Aremu et al., 2007).

The foaming capacity and stability of flour blends ranged from 21.49 to 107.16 $\%$ and 14.42 to $87.29 \%$, while the solubility index, and the least gelation concentration ranged from 20.97 to $52.97 \%$ and 5.00 to $19.00 \%$, respectively. The FC, FS and SI generally increase with increase in the level of soy protein isolate incorporated in the flour blends, while the least gelation concentration decreases. Foam formation has been attributed to the rate of decrease of surface tension of the air/water interface caused by absorption of protein molecules (Sathe et al., 1982). The increasing solubility index with increasing protein isolate substitution for rice flour may be due to the increasing protein content of the flours. Gelation property is dependent on the nature of protein, starch and gums in the flour as well as their interaction during treatments (OmowaiyeTaiwo et al., 2014). NRTwPI and FRTwPI blends with higher gelation properties may be better ingredients in food applications involving gel formation.

\section{Pasting profile of rice-soy protein isolate flour blends}

Pasting characteristics of flour blends is depicted in Table 3. The range of value of peak viscosity (PV), trough viscosity (TV), breakdown viscosity (BV), fina viscosity (FV) and setback viscosity (SV) are 128-355 cP, 98.67-251.00 cP 31.00-104.00 cP, 198.67-1188.00 $\mathrm{cP}$ and 99.67-922.67 $\mathrm{cP}$ respectively. In addition, the pasting viscosity varied significantly among the flour blends. Moreover, as the level of soy protein isolates increases in the blend, there was general reduction in pasting characteristics. Similar observation was reported by Tharise et al. (2014) for composite flour blends of cassava, rice, potato, soybean and xanthan gum. Nerica 7 rice flour and its composite blends generally showed higher pasting characteristics than their Faro 44 whole rice and composite blend counterparts. The relative low peak viscosity of the sample with higher protein isolate content shows that they may find use in products requiring low gel strength and elasticity (Abioye et $\boldsymbol{a l} ., 2011$ ). The final viscosity indicates reassociation of starch granules during cooling after gelatinization and formation of gel network (Chanapamokkhot and Thongngam, 2007). The lower breakdown and final viscosity with increase in soybean flour has been reported to be an indication of the ability of the flour to form viscous gel or paste after cooking and cooling (Abioye et al., 2011). The lower setback viscosity of the flour blends with increasing level of soybean protein isolates indicates more retrogradation during cooling and greater tendency of staling of the products produced from the flours.

The pasting temperature ranged from $94.80{ }^{\circ} \mathrm{C}$ (NRFvPI) to $95.03{ }^{\circ} \mathrm{C}$ (FRFvPI) There was no significant difference observed in the pasting temperature of the flour blends. The range of pasting temperature is higher than 71.35 to $77.80{ }^{\circ} \mathrm{C}$ range reported for composite flours reported by Tharise et al. (2014). Pasting temperature gives information on the minimum temperature required for heating or gelatinizing flour. The pasting time ranged from 7.03 to $7.13 \mathrm{~min}$ in FRTwPI and NRW respectively.

Table 3 Pasting properties of rice-soy protein isolate flour blends

\begin{tabular}{lllllllc}
\hline Sample & $\mathbf{P V}(\mathbf{c P})$ & $\mathbf{T V}(\mathbf{c P})$ & $\mathbf{B V}(\mathbf{c P})$ & $\mathbf{F V}(\mathbf{c P})$ & $\mathbf{S V}(\mathbf{c P})$ & $\left.\mathbf{P T e m p} \mathbf{(}^{\mathrm{o}} \mathbf{C}\right)$ & PTime \\
\hline NRW & $355.00 \pm 11.53^{\mathrm{a}}$ & $251.00 \pm 8.00^{\mathrm{a}}$ & $104.00 \pm 3.61^{\mathrm{a}}$ & $1188.00 \pm 61.49^{\mathrm{a}}$ & $922.67 \pm 45.45^{\mathrm{a}}$ & $94.94 \pm 0.12^{\mathrm{ab}}$ & $7.13 \pm 0.01^{\mathrm{a}}$ \\
FRW & $253.00 \pm 1.00^{\mathrm{c}}$ & $198.00 \pm 2.00^{\mathrm{c}}$ & $55.0 \pm 1.00^{\mathrm{d}}$ & $382.67 \pm 3.06^{\mathrm{e}}$ & $183.00 \pm 1.00^{\mathrm{f}}$ & $95.00 \pm 0.04^{\mathrm{a}}$ & $7.05 \pm 0.06^{\mathrm{bc}}$ \\
NRFvPI & $308.67 \pm 13.05^{\mathrm{a}}$ & $219.67 \pm 8.50^{\mathrm{b}}$ & $88.33 \pm 1.00^{\mathrm{b}}$ & $968.00 \pm 22.51^{\mathrm{b}}$ & $749.33 \pm 14.01^{\mathrm{b}}$ & $94.80 \pm 0.20^{\mathrm{ab}}$ & $7.12 \pm 0.03^{\mathrm{ab}}$ \\
FRFvPI & $207.00 \pm 1.00^{\mathrm{d}}$ & $157.33 \pm 1.52^{\mathrm{e}}$ & $49.0 \pm 2.00^{\mathrm{e}}$ & $317.33 \pm 6.40^{\mathrm{f}}$ & $158.67 \pm 7.09^{\mathrm{fg}}$ & $95.03 \pm 0.04^{\mathrm{a}}$ & $7.05 \pm 0.06^{\mathrm{bc}}$ \\
NRTnPI & $242.67 \pm 1.15^{\mathrm{c}}$ & $178.00 \pm 2.00^{\mathrm{d}}$ & $65.33 \pm 3.05^{\mathrm{c}}$ & $693.67 \pm 4.70^{\mathrm{c}}$ & $516.00 \pm 6.56^{\mathrm{c}}$ & $95.00 \pm 0.01^{\mathrm{a}}$ & $7.07 \pm 0.06^{\mathrm{abc}}$ \\
FRTnPI & $190.00 \pm 2.00^{\mathrm{e}}$ & $144.67 \pm 2.52^{\mathrm{f}}$ & $45.67 \pm 0.58^{\mathrm{e}}$ & $290.00 \pm 2.00^{\mathrm{f}}$ & $144.33 \pm 3.51^{\mathrm{gh}}$ & $95.00 \pm 0.01^{\mathrm{a}}$ & $7.12 \pm 0.03^{\mathrm{ab}}$ \\
NRFtPI & $203.00 \pm 2.00^{\mathrm{de}}$ & $154.00 \pm 2.00^{\mathrm{ef}}$ & $49.67 \pm 1.15^{\mathrm{e}}$ & $551.33 \pm 5.03^{\mathrm{d}}$ & $397.33 \pm 3.05^{\mathrm{d}}$ & $95.00 \pm 0.01^{\mathrm{a}}$ & $7.09 \pm 0.04^{\mathrm{abc}}$ \\
FRFtPI & $162.33 \pm 19.50^{\mathrm{f}}$ & $120.67 \pm 14.00^{\mathrm{g}}$ & $36.33 \pm 5.51^{\mathrm{f}}$ & $247.67 \pm 31.56^{\mathrm{g}}$ & $120.33 \pm 17.50^{\mathrm{i}}$ & $95.00 \pm 0.01^{\mathrm{a}}$ & $7.06 \pm 0.04^{\mathrm{abc}}$ \\
NRTwPI & $159.66 \pm 6.50^{\mathrm{f}}$ & $120.00 \pm 6.00^{\mathrm{g}}$ & $40.00 \pm 1.00^{\mathrm{f}}$ & $411.67 \pm 10.60^{\mathrm{e}}$ & $291.67 \pm 4.73^{\mathrm{e}}$ & $95.00 \pm 0.01^{\mathrm{a}}$ & $7.09 \pm 0.03^{\mathrm{abc}}$ \\
FRTwPI & $128.33 \pm 3.51^{\mathrm{g}}$ & $98.67 \pm 4.16^{\mathrm{h}}$ & $31.00 \pm 1.00^{\mathrm{g}}$ & $198.67 \pm 1.54^{\mathrm{h}}$ & $99.67 \pm 3.79^{\mathrm{i}}$ & $95.00 \pm 0.05^{\mathrm{a}}$ & $7.03 \pm 0.03^{\mathrm{c}}$ \\
\hline
\end{tabular}

Legend: Values are means of triplicates \pm Standard deviation. Values on the same column with different superscripts are significant $(\mathrm{P} \leq 0.05)$ PV- Peak viscosity, TV-Trough viscosity, BV-Breakdown viscosity, FV-Final viscosity, SV-Setback viscosity, PTemp- Pasting temperature and PTime-Pasting time.

Physical properties of cookies made from rice-soy protein isolate flour blends

Figure 1 depicts the physical properties of the cookies produced from rice flour (Nerica 7 and Faro 44) blended with soy protein isolate. The width, thickness and weight of the cookies ranged from 2.06-3.04 cm, 0.97-1.45 cm and 6.15-6.35 g respectively, and they increase generally with increase in soy protein isolate. The spread ratio of the cookies ranged from 2.12 to 3.08. Cookies produced from the blend of NRTnPI (Nerica 7 rice flour supplemented with $10 \%$ protein isolate) had the highest spread ratio, while those from NRW (whole Nerica 7 rice flour) had the least. High spread ratio is desired in cookies (Kirssel and Prentice, 1979). Low spread ratio has been attributed to very hydrophilic nature of starches in the flour used for cookies (Okpala and Egwu, 2015). The flour blend, NRTnPI, may be a better ingredient in production of cookies. It was observed that cookies with the least spread ratio have the least thickness and width, this is contrary to the observation of Okpala et al., (2014), but similar to that of Man et al. (2014). The determination of physical properties of cookies would help in the design of package. 


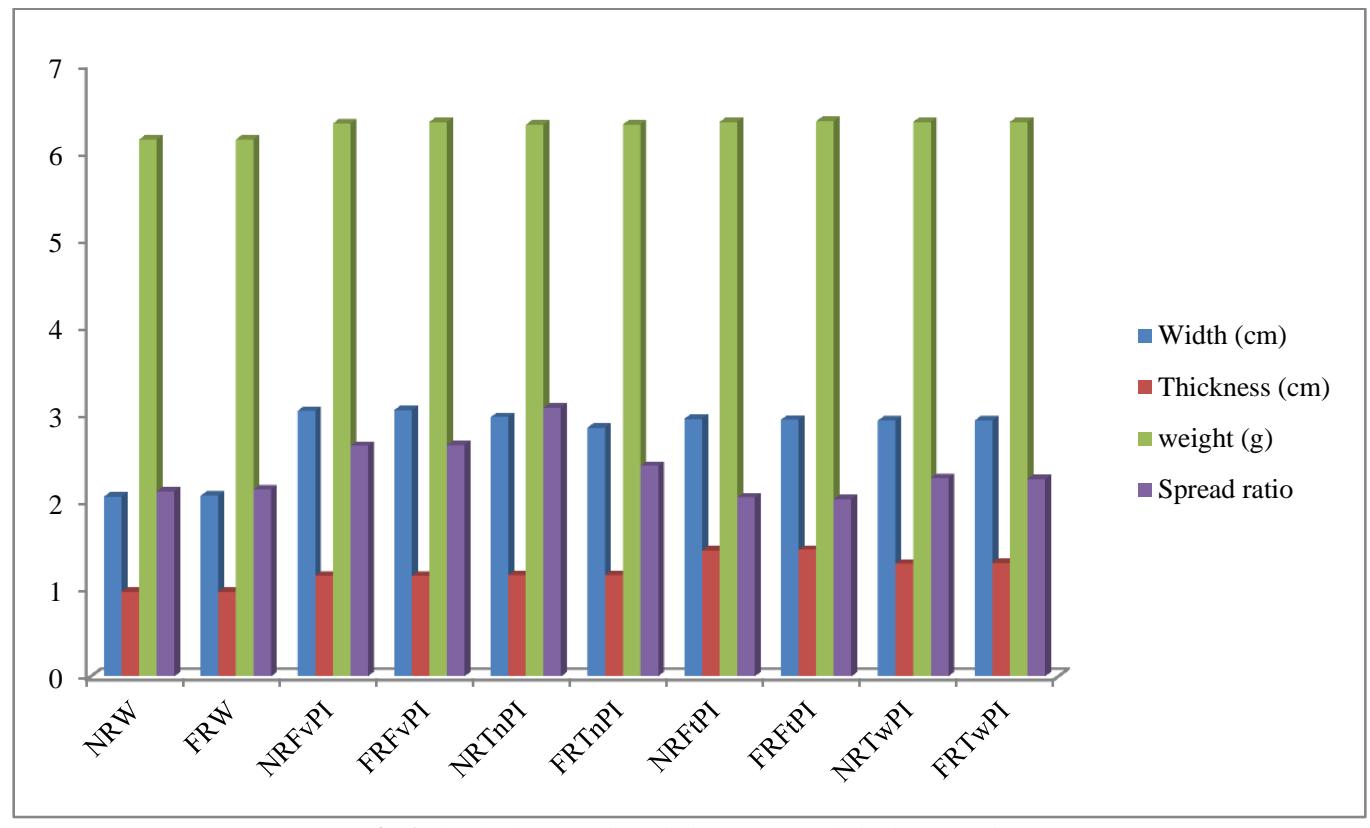

Fig 1 Physical properties of rice-soy protein isolate cookies

\section{Proximate composition of cookies}

Proximate composition of the cookies produced from rice-soy protein isolate flour blends is shown in Table 4 . The proximate composition varied significantly $(\mathrm{p} \leq 0.05)$. The moisture content ranged from $3.28 \mathrm{~g} / 100 \mathrm{~g}(\mathrm{NRW})$ to $5.33 \mathrm{~g} / 100 \mathrm{~g}$ (NRFtPI). The range of values of moisture content of the cookies is lower than $6.11 \%$ moisture in cookies from plantain-based composite flour (Osundahunsi et al., 2010) and 6.56 to $7.89 \%$ for biscuits reported by Okpala and Egwu (2015). The range of moisture content obtained in this study is also lower than the range of 7.46 to $10.23 \%$ reported by Okpala et al. (2013) for cookies made from germinated pigeon pea, fermented sorghum and blanched cocoyam flour blends and 8.64 to $8.73 \%$ reported for cookies from composite flour containing brewer's spent grain (Okpala and Ofoedu, 2018). The relatively low moisture content of the cookies in the present study may be an indication of higher shelf stability of the cookies. The moisture content of the cookies in this study increased significantly with inclusion of soybean protein isolate. This may be due to higher water binding capacity of legume protein

Table 4 Proximate composition $(\mathrm{g} / 100 \mathrm{~g})$ of cookies made from rice-soy protein isolate blends

\begin{tabular}{|c|c|c|c|c|c|c|}
\hline Sample & Moisture & Ash & Protein & Crude Fibre & Crude Fat & Carbohydrate \\
\hline NRW & $3.28 \pm 0.08^{\mathrm{e}}$ & $5.98 \pm 0.02^{b}$ & $4.34 \pm 0.03^{h}$ & $4.22 \pm 0.11^{\mathrm{a}}$ & $0.31 \pm 0.01^{\mathrm{g}}$ & $81.87 \pm 0.17^{\mathrm{a}}$ \\
\hline FRW & $3.85 \pm 0.01^{\mathrm{d}}$ & $6.99 \pm 0.02^{\mathrm{a}}$ & $3.96 \pm 0.02^{\mathrm{i}}$ & $4.13 \pm 0.11^{\mathrm{a}}$ & $0.21 \pm 0.01^{\mathrm{h}}$ & $80.87 \pm 0.13^{b}$ \\
\hline NRFvPI & $4.41 \pm 0.08^{c}$ & $4.65 \pm 0.05^{\mathrm{f}}$ & $8.78 \pm 0.03^{\mathrm{g}}$ & $3.09 \pm 0.06^{\mathrm{f}}$ & $0.88 \pm 0.01^{\mathrm{d}}$ & $78.19 \pm 0.07^{\mathrm{c}}$ \\
\hline FRFvPI & $4.42 \pm 0.04^{\mathrm{c}}$ & $4.75 \pm 0.05^{\mathrm{e}}$ & $8.56 \pm 0.02^{\mathrm{g}}$ & $3.15 \pm 0.10^{\mathrm{f}}$ & $0.80 \pm 0.02^{\mathrm{f}}$ & $78.32 \pm 0.11^{\mathrm{c}}$ \\
\hline NRTnPI & $4.84 \pm 0.57^{\mathrm{b}}$ & $4.94 \pm 0.03^{\mathrm{c}}$ & $11.41 \pm 0.18^{\mathrm{e}}$ & $3.50 \pm 0.02^{\mathrm{e}}$ & $0.91 \pm 0.01^{\mathrm{c}}$ & $74.40 \pm 0.62^{\mathrm{e}}$ \\
\hline FRTnPI & $4.52 \pm 0.02^{\mathrm{bc}}$ & $4.85 \pm 0.03^{\mathrm{d}}$ & $10.39 \pm 0.18^{\mathrm{f}}$ & $3.41 \pm 0.01^{\mathrm{e}}$ & $0.81 \pm 0.01^{\mathrm{f}}$ & $76.03 \pm 0.16^{\mathrm{d}}$ \\
\hline NRFtPI & $5.18 \pm 0.03^{\mathrm{a}}$ & $4.98 \pm 0.03^{\mathrm{c}}$ & $14.29 \pm 0.04^{\mathrm{c}}$ & $3.72 \pm 0.03^{\mathrm{cd}}$ & $0.95 \pm 0.01^{\mathrm{b}}$ & $70.87 \pm 0.34^{\mathrm{g}}$ \\
\hline FRFtPI & $5.33 \pm 0.06^{\mathrm{a}}$ & $4.99 \pm 0.01^{\mathrm{c}}$ & $13.39 \pm 0.04^{\mathrm{d}}$ & $3.62 \pm 0.03^{\mathrm{d}}$ & $0.85 \pm 0.01^{\mathrm{e}}$ & $71.81 \pm 0.01^{\mathrm{f}}$ \\
\hline NRTwPI & $4.80 \pm 0.02^{b}$ & $4.94 \pm 0.01^{\mathrm{c}}$ & $17.76 \pm 0.23^{\mathrm{a}}$ & $3.96 \pm 0.04^{\mathrm{b}}$ & $0.98 \pm 0.01^{\mathrm{a}}$ & $67.56 \pm 0.23^{\mathrm{i}}$ \\
\hline FRTwPI & $5.18 \pm 0.03^{\mathrm{a}}$ & $4.84 \pm 0.02^{\mathrm{d}}$ & $16.63 \pm 0.23^{\mathrm{b}}$ & $3.82 \pm 0.02^{\mathrm{c}}$ & $0.88 \pm 0.01^{\mathrm{d}}$ & $68.66 \pm 0.21^{\mathrm{h}}$ \\
\hline
\end{tabular}

Legend: Values are means of triplicates \pm Standard deviation. Values on the same column with different superscripts are significant (P $\leq 0.05$ ).

The protein content of the rice-soy protein isolate cookies was highest in NRTwPI (17.76 g/100g) with FRW having the least value of $3.96 \mathrm{~g} / 100 \mathrm{~g}$. The protein content increased with increased level of soy protein isolate in the flour blends; this may be due to significant quantity of protein in the isolate. Similar observation was reported for cookies from composite flour of maize and soy protein isolates (Adeyeye et al., 2017). The values obtained for protein content in this study compared favourably with the ranges of 7.37 to $21.4 \%$ (Okpala et al. 2013) and 13.75 to $21.65 \%$ (Abayomi et al., 2013) reported for cookies produced from germinated pigeon pea, fermented sorghum and blanched cocoyam flour blends and cookies from blends of sweet potato and fermented soybean flour respectively. The high protein content of soy protein isolate supplemented cookies would be of nutritional significant especially in developing countries like Nigeria where high protein foods are costly and thus unaffordable by the majority of the populace, especially those below the poverty line.

Ash and crude fibre reduced with increased protein isolate inclusion, while crude fat increased. The increase in fat content with protein isolate addition could be due to increase fat binding properties of soy protein. NRTwPI had the lowest carbohydrate content of $67.56 \mathrm{~g} / 100 \mathrm{~g}$, while NRW had the highest value of 81.87 $\mathrm{g} / 100 \mathrm{~g}$. The range compared favourably with the range of values of carbohydrate of some cookies and biscuits produced from gluten-free composite flours (Falola et al., 2011; Abayomi et al., 2016). The lower carbohydrate content of cookies made from composite blends of rice and soy protein isolate may be of advantage in therapeutic diet for obese and diabetics.

\section{Sensory Attributes of Cookies}

The results of sensory scores of rice-soy protein isolate cookies are depicted in Table 5. The cookies varied significantly in all the sensory parameters evaluated The whole rice cookies (NRW and FRW) were scored lower than their composite blend counterparts in all the sensory properties evaluated. Cookies made from rice-soy protein isolate blends were generally preferred to their whole rice flour cookies for taste, colour, crispiness and overall acceptability. Cookies sample NRFtPI (Nerica 7 rice blended with $15 \%$ soy protein isolate) is scored highest in taste, texture, crispiness and overall acceptability. Composite blends of Nerica 7 or Faro 44 rice and soy protein isolate may be a better ingredient in preparation of functional gluten free cookies. 
Table 5 Sensory properties of cookies made from rice-soy protein isolate blends

\begin{tabular}{lllllll}
\hline Sample & Taste & Colour & Flavour & Texture & Crispiness & $\begin{array}{l}\text { Overall } \\
\text { Acceptability }\end{array}$ \\
\hline NRW & $5.00 \pm 1.76^{\mathrm{b}}$ & $5.80 \pm 1.23^{\mathrm{c}}$ & $6.50 \pm 1.08^{\mathrm{a}}$ & $6.60 \pm 1.71^{\mathrm{a}}$ & $5.50 \pm 1.27^{\mathrm{c}}$ & $5.00 \pm 1.56^{\mathrm{b}}$ \\
FRW & $5.20 \pm 1.69^{\mathrm{b}}$ & $5.20 \pm 1.48^{\mathrm{c}}$ & $6.50 \pm 1.08^{\mathrm{a}}$ & $6.70 \pm 1.16^{\mathrm{a}}$ & $5.90 \pm 1.37^{\mathrm{bc}}$ & $4.70 \pm 1.16^{\mathrm{b}}$ \\
NRFvPI & $6.90 \pm 1.10^{\mathrm{a}}$ & $6.70 \pm 1.06^{\mathrm{ab}}$ & $7.10 \pm 1.10^{\mathrm{a}}$ & $6.80 \pm 1.75^{\mathrm{a}}$ & $7.70 \pm 1.34 \mathrm{a}$ & $7.60 \pm 0.97^{\mathrm{a}}$ \\
FRFvPI & $6.90 \pm 1.28^{\mathrm{a}}$ & $6.60 \pm 1.07^{\mathrm{ab}}$ & $6.50 \pm 1.51^{\mathrm{a}}$ & $6.20 \pm 1.55^{\mathrm{a}}$ & $7.40 \pm 1.07^{\mathrm{a}}$ & $7.00 \pm 1.15^{\mathrm{a}}$ \\
NRTnPI & $6.90 \pm 1.60^{\mathrm{a}}$ & $6.30 \pm 1.34^{\mathrm{abc}}$ & $6.60 \pm 1.50^{\mathrm{a}}$ & $6.00 \pm 1.69^{\mathrm{a}}$ & $7.40 \pm 1.90^{\mathrm{a}}$ & $7.40 \pm 1.26^{\mathrm{a}}$ \\
FRTnPI & $7.30 \pm 1.41^{\mathrm{a}}$ & $6.70 \pm 1.06^{\mathrm{ab}}$ & $6.70 \pm 1.70^{\mathrm{a}}$ & $7.10 \pm 1.20^{\mathrm{a}}$ & $7.80 \pm 1.23^{\mathrm{a}}$ & $7.70 \pm 0.82^{\mathrm{a}}$ \\
NRFtPI & $7.70 \pm 1.25^{\mathrm{a}}$ & $6.50 \pm 0.71^{\mathrm{ab}}$ & $7.00 \pm 1.83^{\mathrm{a}}$ & $7.40 \pm 0.97^{\mathrm{a}}$ & $7.70 \pm 1.25^{\mathrm{a}}$ & $7.70 \pm 0.82^{\mathrm{a}}$ \\
FRFtPI & $7.00 \pm 1.05^{\mathrm{a}}$ & $6.70 \pm 1.06^{\mathrm{ab}}$ & $6.30 \pm 1.57^{\mathrm{a}}$ & $6.90 \pm 0.99^{\mathrm{a}}$ & $6.80 \pm 1.03^{\mathrm{ab}}$ & $7.60 \pm 0.70^{\mathrm{a}}$ \\
NRTwPI & $7.40 \pm 1.42^{\mathrm{a}}$ & $7.20 \pm 1.23^{\mathrm{a}}$ & $6.40 \pm 1.43^{\mathrm{a}}$ & $6.90 \pm 1.29^{\mathrm{a}}$ & $7.30 \pm 1.25^{\mathrm{a}}$ & $7.70 \pm 1.16^{\mathrm{a}}$ \\
FRTwPI & $6.60 \pm 0.96^{\mathrm{a}}$ & $6.50 \pm 1.58^{\mathrm{ab}}$ & $7.00 \pm 1.05^{\mathrm{a}}$ & $6.70 \pm 1.25^{\mathrm{a}}$ & $7.10 \pm 1.37^{\mathrm{ab}}$ & $6.90 \pm 0.88^{\mathrm{a}}$ \\
\hline
\end{tabular}

Legend: Values are means of triplicates \pm Standard deviation. Values on the same column with different superscripts are significant $(\mathrm{P} \leq 0.05)$.

\section{CONCLUSION}

Rice-soy protein gluten-free flour could find use in producing functional cookies with acceptable physical and sensory qualities. These cookies would be an advantage to people suffering from gluten intolerance. The addition of soy protein to rice flour in varying proportions significantly $(p \leq 0.05)$ improved the functional properties and pasting qualities of the flour blends. Also, the physica properties, sensory qualities, and nutrient values of the cookies are enhanced Nerica 7 rice blended with $15 \%$ soy protein isolate flour may find use in the production of enriched and acceptable cookies. This study showed that utilisation of indigenous crops, such as locally cultivated rice in Nigeria could have economic advantage, thus reducing foreign exchange spending on wheat importation, enhance the livelihood of local farmers and also serve as ingredient in food product development.

\section{REFERENCES}

ABAYOMI, H.T., ORESANYA, T.O., OPEIFA, A.O. RASHEED, T.R. 2013. Quality evaluation of cookies produced from blends of sweet potato and fermented soybean flour. International Journal of Nutrition and Food Engineering, 7(7), 639-644

ABIOYE, V.F, ADE-OMOWAYE, B.I.O., BABATUNDE, G.O, ADESIGBIN, M.K. 2011. Chemical, physico-chemical and sensory properties of soy-plantain flour. African Journal of Food Science, 5(4), 176-180. http://www.academicjournals.org/ajfs

ADEYEYE, S.A. AKINGBALA, J.O. 2015. Quality characteristics and acceptability of cookies from sweet potato-maize flour blends. Nutrition and Food Science, 45(5), 703-715 http://doi.org/10.1108/NFS-03-2015-0020

ADEYEYE, S.A.O., ADEBAYO-OYETORO, A.O. OMONIYI, S.A. 2017 Quality and sensory properties of maize flour cookies enriched with soy protein isolate. Cogent Food Agriculture, Doi.org/10.1080/24411932.2017.1278827

AOAC 2010. Official method of analysis of Association of Official Analytical Chemist. $18^{\text {th }}$ Ed Washington DC

AREMU, M.O., OLAOFE, O. AKINTAYO, E.T. 2007. Functional properties of some Nigerian varieties of legume seed flours and flour concentration effect on foaming and gelation Properties. Journal of Food Technology, 5(2), 109-115. http://medwelljournals.com/abstract/?doi=jftech.2007.109.115

BESWA, D., DLAMINI, N.R., SIWELA, M., AMONSOU, E.O., KOLANISI, U 2016. Effect of amaranth addition on the nutritional composition and consumer acceptability of extruded provitamin A-biofortified maize snacks. Food Science \& Technology, 36(1), 30-39. DOI:10.1590/1678-457X.6813

CHANAPAMOKKOT, H. THONGNGAM, M. 2007. The chemical and physicochemical properties of sorghum starch and flour. Journal of Natural Science, 41, 343-349

CHANDRA, S., SINGH, S., KUMARI, D. 2015. Evaluation of functiona properties of composite flours and sensorial attributes of composite flour biscuits Journal of Food Science and Technology, 52(6), 3681-3688. DOI: 10.1007/s13197-014-1427-2

COFFMAN, C.W. GARCIA, V.V. 1977. Functional properties and amino acid content of a protein isolate from mung bean flour. Journal of Food Technology, 12(5), 473-484. https://doi.org/10.1111/j.1365-2621.1977.tb00132.x

DA SILVA, T.F., CONTI-SILVA, A.C. 2016. Preference mappings for glutenfree chocolate cookies: Sensory and physical characteristics, Nutrition \& Food Science, 46(3), 374-387. https://doi.org/10.1108/NFS-11-2015-0139

FALOLA, A.O., OLATIDOYE, O.P., BALOGUN, I.O. OPEIFA, A.O. 2011. Quality characteristics of cookies produced from composite flours of cassava and Cucurbita mixta seed. Journal of Agriculture and Veterinary Science, 3, 1-12

FOSCHIA, M., HORSTMANN, S.W., ARENDT, E.K., ZANNINI, E. 2017. Legumes as functional ingredients in gluten-free bakery and pasta products Annual Rev. Food Science and Technology. 8, 75-96. https://doi.org/10.1146/annurev-food-030216-030045.

IGE, M.M., OGUNSUA, A.O. OKE, O.L. 1984. Functional properties of the proteins of some Nigerian oilseeds: Conophor seeds and three varieties of melon seeds. Journal of Agriculture and Food Chemistry, 32(4), 822-825
IITA 2001. Operation manual for the series 3 rapid visco analyzer using thermocline for windows. Newport Scientific pty Lmd. Standard Univ. Press. Stanford, CA, USA, 315

IWE, M.O. EGWUEKE, E.J. 2010. Production and evaluation of cookies from Anthosoma sagitifolium and Colocasia esculenta blends. Nigerian Food Journal, 27(1), 145-153

JITNGARMKUSOL, S., HONGSUWANKUL, J. \& TANANUWONG, K. 2008 Chemical composition, functional properties and microstructure of defatted Macademice flours. Food Chemistry, 110, 23-30. https://doi.org/10.1016/j.foodchem.2008.01.050

KIRSSEL, L. PRENTICE, M. 1979. Protein and fibre enrichment of cookies flour with Brewer's spent grain. Cereal Chemistry, 50, 261-265

LEACH, H.W., McCOWAN, L.D. SCHOCH, T.J. 1959. Structure of the starch granule I, swelling power and solubility patterns of different starches. Cereal Chemistry, 36, 534-544.

MAN, S., PAUCEAN, A. MUSTE, S. 2014. Preparation and quality evaluation of gluten-free biscuits. Bulletin UASVM Food Science \& Technology 71(1), 38-44 DOI: http://dx.doi.org/10.15835/buasvmcn-fst:10080

NORAZMIR, M., MASTURA, K., BARIAH, A., DEVI, M., SABARIAH, B. 2014. Development of whole grain carrot (Daucus carota) chips. Curr. Res Nutrition and Food Science, 2(1), 26-32. http://dx.doi.org/10.12944/CRNFSJ.2.1.04

OGUNBUSOLA, E.M., FAGBEMI, T.N. OSUNDAHUNSI, O.F. 2012. In-vitro digestibility and functional Properties of Lagenaria siceraria protein isolates. Journal of Applied and Environmental Science, 7(1), 1-7

OKPALA, L.C., EGWU, P.N. 2015. Utilization of broken rice and cocoyam flour blends in the production of biscuits. Nigerian Food, 33(1), 8-11. https://doi.org/10.1016/j.nifoj.2015.04.010

OKPALA, L.C., OFOEDU, P.I. 2018. Quality characteristics of cookies produced from sweet potato and wheat flour blend fortified with Brewer's spent grain flour. Current Research in Nutrition and Food Science, 6(1), 113-119. DOI http://dx.doi.org/10.12944/CRNFSJ.6.1.12

OKPALA, L.C., OKOLI, E. UDENSI, E. 2013. Physico-chemical and sensory properties of cookies made from blends of germinated pigeon pea, fermented sorghum and cocoyam flours. Food Science and Nutrition, 1(1), 8-14 doi: $[10.1002 / \mathrm{fsn} 3.2]$

OMOWAIYE-TAIWO, O.A., FAGBEMI, T.N., OGUNBUSOLA, E.M BADEJO, A.A. 2014. Effect of germination and fermentation on the proximate composition and functional properties of full-fat and defatted Cucumeropsis mannii seed flours. Journal of Food Science and Technology, 52(8), 5257-5263 doi: [10.1007/s13197-014-1569-2]

OSUNDAHUNSI, O.F., SEIDU, K.T. OYERINDE, O.V. 2010. Potential of African pear (Dacryodes edulis) as an ingredient in plantain-based composite cookies. Nutrition and Food Science, 40(1), 39-48. https://doi.org/10.1108/00346651011015908

PELLEGRINI, N., AGOSTONI, C. 2015. Nutritional aspect of gluten-free products. Journal of Science of Food and Agriculture, 95(12), 2380-2385. Doi 10.1002/jsfa.7101

PESTORIC, M., SKROBOT, D., ZIGON, U., SIMURINA, O., FILIPCEV, B., BELOVIC, M., MISAN, A. 2017. Sensory profile and preference mapping of cookies enriched with medicinal herbs. International Journal of Food Properties. http://dx.doi.org/10.1080/10942912.2016.1160922.

SANUSI, M.S., AKINOSO, R. DANBABA, N. 2017. Evaluation of physical, milling and cooking properties of four new rice (Oryza sativa) varieties in Nigeria. International Journal of Food Studies, 6, 245-256. DOI 10.7455/ijfs/6.2.2017.a10

SATHE, S.K., DESPHANDE, S.S. SALUNKHE, D.K. 1982. Functional properties of lupin seed (Lupinus mutabilis) protein and protein concentrates Journal of Food Science, 47, 491-497. https://doi.org/10.1111/j.13652621.1982.tb10110.x

SIDDIQUI, N.R., HASSAN, M., RAZA, S., HAMEED, T. KHALIL, S. 2003 Sensory and physical evaluation of biscuits supplemented with soy flour. Pakistan Journal of Food Science, 12, 45-48

THARISE, N., JULIANTI, E. NURMINAH, M. 2014. Evaluation of physicochemical and functional properties of composite flour from cassava, rice, potato, 
soybean and xanthan gum as Alternative of wheat flour. International Food Research Journal, 21(4), 1641-1649

UDENSI, E.A. OKORONKWO, K.A. 2006. Effects of Fermentation and germination on the physicochemical properties of Mucuna cochinchinensis protein isolate. African Journal of Biotechnology, 5(10), 896-900

WU, J.H., NEAL, B., TREVENA, H., CRINO, M., STUART-SMITH, W., FAULKNER-HOQQ, K., YU LOUIE, J.C., DUNFORD, E. 2015. Are glutenfree food healthier than non-gluten-free foods? An evaluation of supermarket products in Australia. Br. Journal of Nutrition, 114(3), 448-454. Doi: $10.1017 / \mathrm{S} 00071145115002056$ 